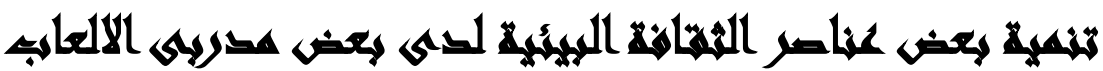

\section{اللرياخية}

$[1 \cdot]$

محمد السيد محمد ديب(')- عبد المسيح سمعان عبد المسيح(')

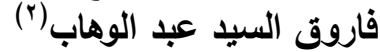

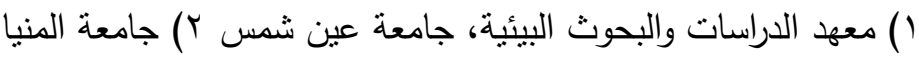

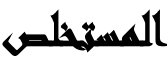

هدفت هذه الدراسة إلى تتمية بعض عناصر الثقافة البيئية (المعارف البيئية والاتجاهات البيئية) وذللك من خلال برنامج يعد خصيصاً لذللك.

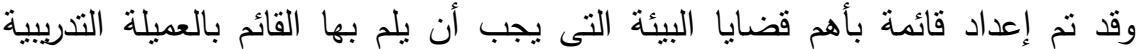

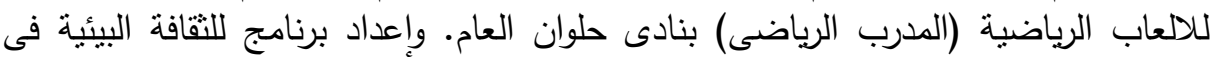
ضوئها، ثم تم إعداد مقياس لقياس الثقافة البيئية يقدم لهؤلاء المدربين.

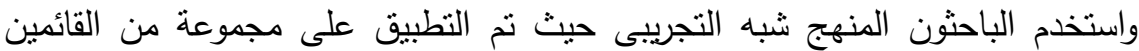

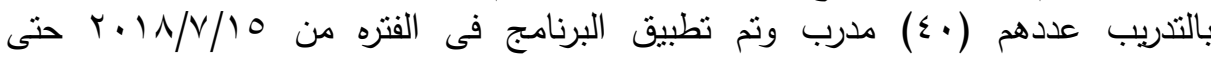

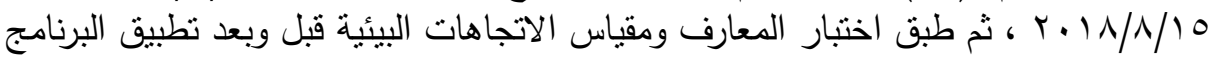

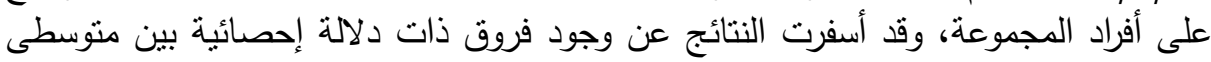

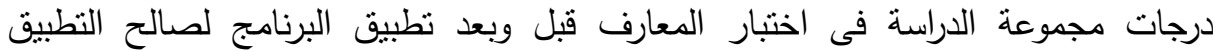

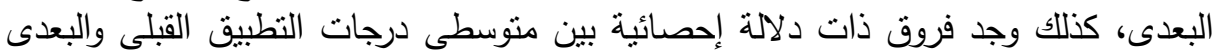
من مقياس الاتجاهات البيئية لمجموعة الدراسة لصالح التطبية لئيق البعدى، مما يشير إلى فاعلية

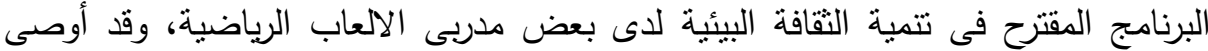
الباحثّن بضرورة الاستفادة من البرنامج المقترح.

\section{Iasadl}

الثقافة هي روح الأمة وعنوان هويتها، وهي من الركائز الأساسيه في بناء الأمم وفي نهوضها، فلكل أمة نقافُة نستمدّ منها عناصرها ومقوماتها وخصائصها، وتصطبغ بصبغتها، فتتسب إليها. وكل مجتمع له نقافتُه التي ينسم بها، ولكل ثقافة مميزاتها وخصائصها. ويعرف

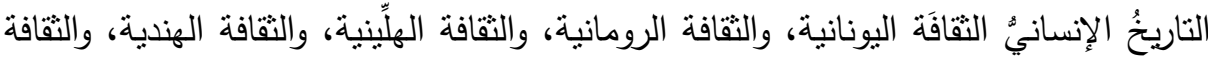

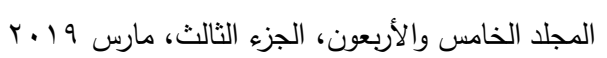


المصرية الفرعونية، والثقافة الفارسية. ولما استلم العرب زمام القيادة الفكرية والتقافية والعلمية للبشرية في القرن السابع للميلاد، واستمروا في مركزهم المتميّز إلى القرن الخامس عشر منس منهاه،

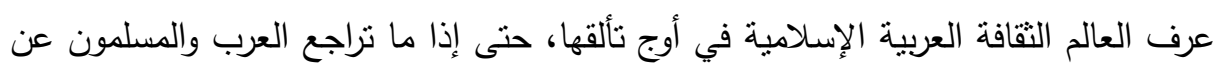

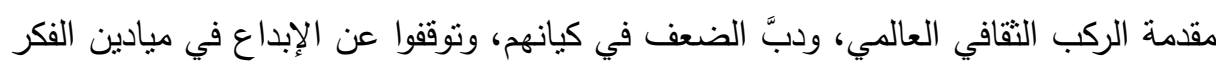

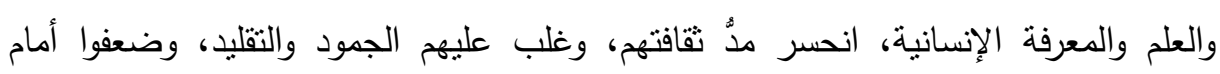

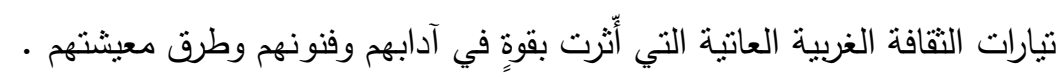
والثقافة كلمة عريقة في اللغة العربية أصلا، فهي تعني صقل النفس والمنطق والفطانة،

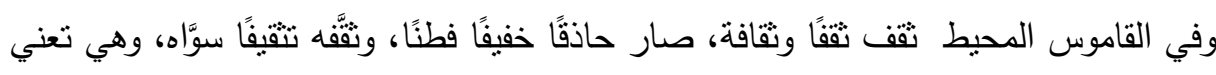
تثقيف الرمح، أي تسويته وتقويمه. واستعملت الثقافة في العصر الحديث للالالة على الرقيّ

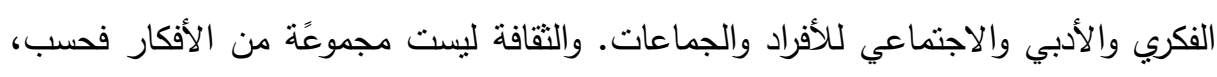

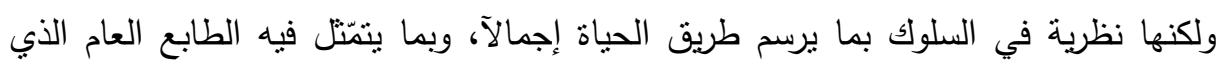

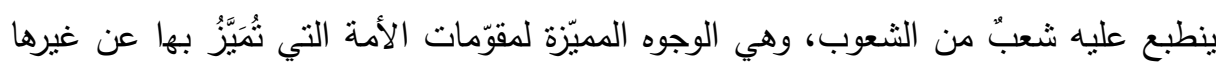

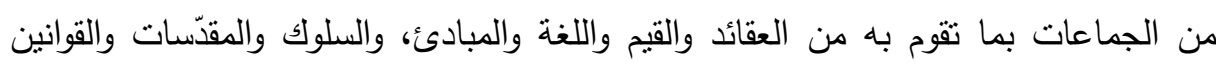

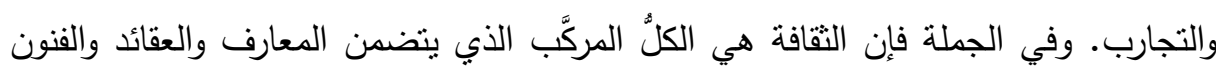

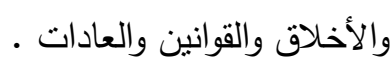
إنّ الثقافة أعمٌ من العلم وأثنمل، ذلك لأن العلم موضوعه الأشياء المادية، كما هي الحال

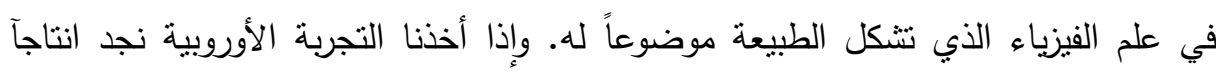

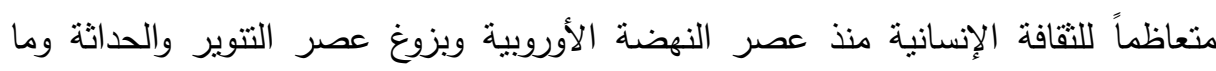
بعدها، ولكنها ساهمت أيضاً في ترسيخ مفهوم مركزية الإنسان في الطبيعة الذي نرتبت عليه الإنيه

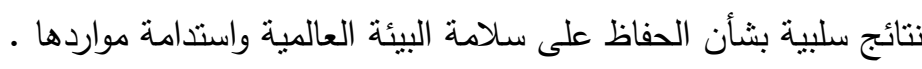

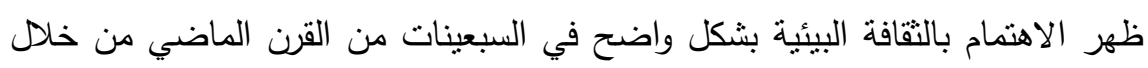
عقد اللقاءات، والندوات، والمؤتمرات المتخصصة في هذا المجال والموجهة لمناقتشة قضايا البيئة، والثقافة البيئية بشكل شمولي، والثقافة البيئية مفهوم مركب يشمل الجانب التربوي،

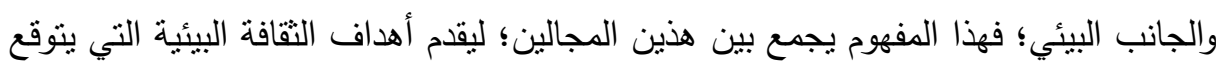

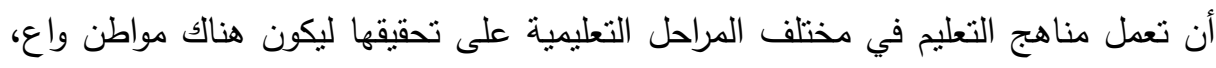


ومهتم بالبيئة وقضاياها، ومدركا لمشكلاتها، ولديه معارف، ومعلومات، ومهارات تمكنه من

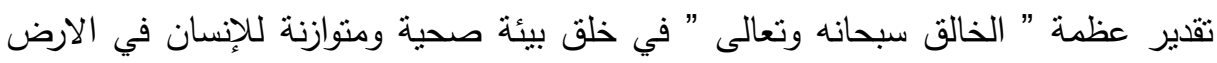

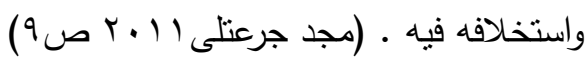

\section{And}

قام الباحثون بدراسة إسنطلاعية بتطبيق أن أحد مقاييس الثقافة البيئية على مجموعة

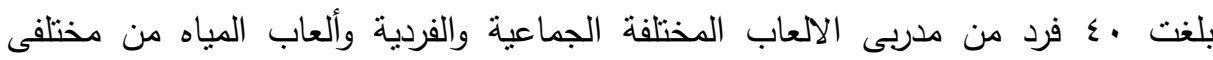

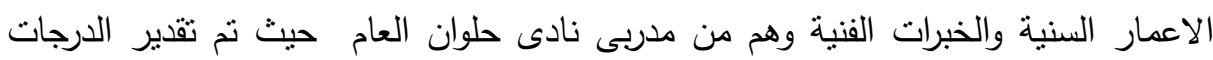

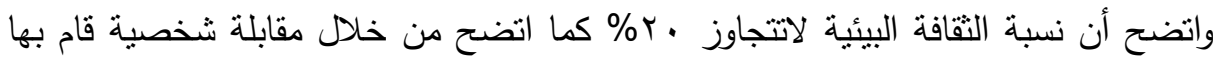

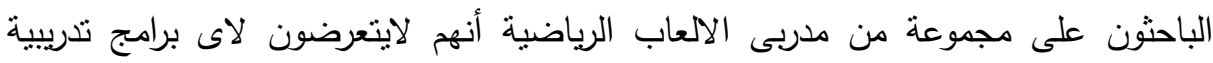
تخص الثقافة البيئية .

\section{أسئلا المهمش}

1- مالقضايا البيئية التى يجب أن تقدم لمدربى الالعاب الرياضيه ؟

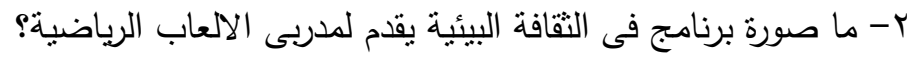

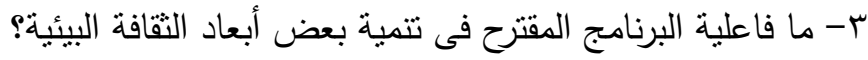

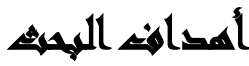

هدف البحث إلى: تتمية بعض عناصر الثقافة البيئية لدى بعض مدربى الالعاب الرياضية.

\section{أهمية المهمه}

يمكن أن بستفيد من هذالبرنامج الفئات التالية: اـ المدربين العاملين فى المجال الرياضى: وذلك من خلال تتفيذ برامج التقافة البيئية للممارسة r ـ للاعبين الممارسين للنشاط الرياضى أنفسهخ 
r ـ للقائعين على إدارة النشاط الرياضى من مستوى المدير وحتى مسنوى مسئولى الملاعب. ع - يقدم أدوات وبرنامج تفيد باحثون أخرون.

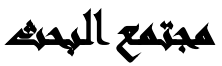

$$
\text { مدربي الالعاب الرياضيه }
$$

\section{هزوغ الهمثن}

الفرض الأول: توجد فروق ذات دلالة إحصائية بين متوسطى درجات أفراد المجموعة

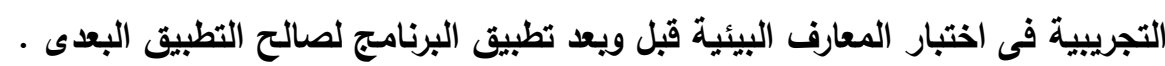
الفرض الثانى: توجد فروق ذات دلالة إحصائية بين متوسطى درجات أفراد المجموعة

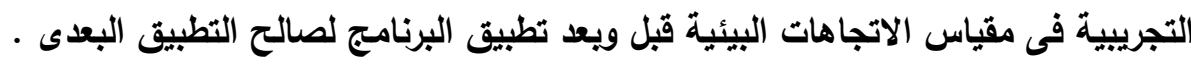

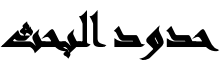

يلتزم البحث بالحدود التالية:

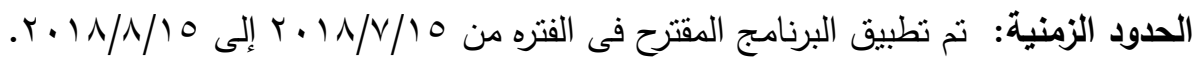
الحدود البشرية: ثلاثتن من المدربين الرياضين.

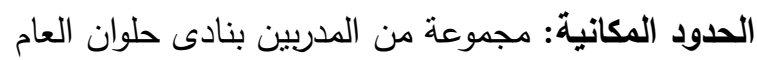

أدوات البحث: تعتمد الدراسة الحالية على استخدام الادوات التالية:

أولا: برنامج للثقافة البيئية

ثانياً: مقياس للثقافة البيئية

\section{منهمج البهمث}

المنهج شبه تجريبى استخدمه الباحثون فى تجريب البرنامج على مجموعة من المدربين وذلك

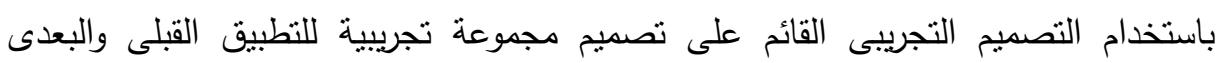
لأدوات البحث 


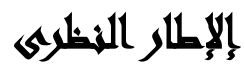

الثقافة البيئية: تعتبر الثقافة البيئية مطلب اساسي لكل مواطن يعيش هذا العصر بكفائة ،

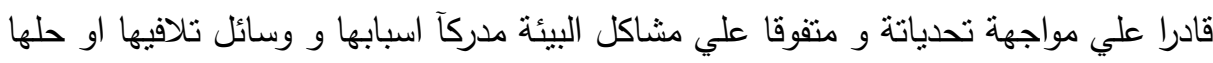

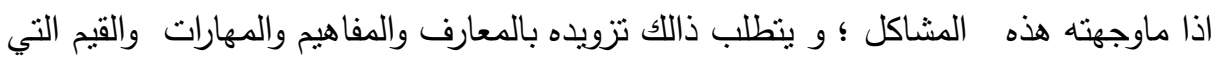
تساعده علي مواجة الظروف البيئية بكفائة ـ ولا بد من التعرف علي ابعاد الثقافة البيئية وتحديدها كي تكون هذه الابعاد اساس لتخطيط برامج التقيف والتعليم البيئ النظامى وغير

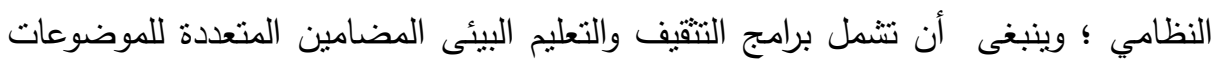

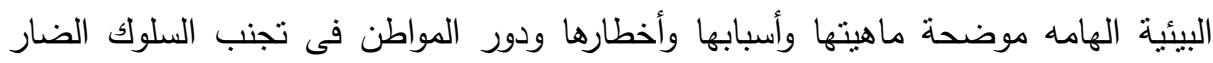

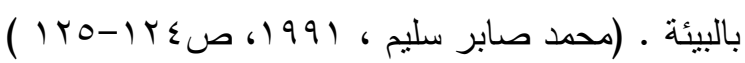

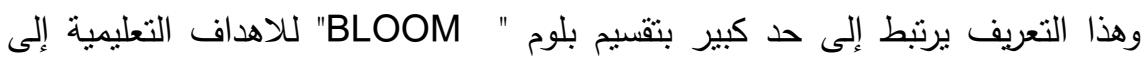

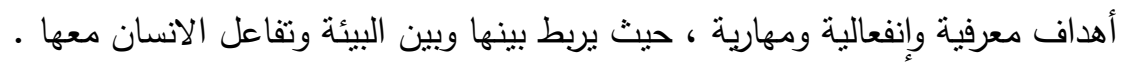
(بينما يرى عبد السلام مصطفى عبد السلام أن الثقافة البيئية " هى المعرفة والاتجاهات

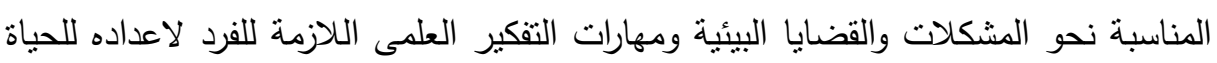
كمواطن قادر على تحديد وحل المشكلات البيئية القائمة والتعامل السليم مع البيئة "

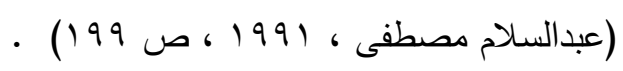
أما هارفى " HARVEY " فيرى أن التقافة البيئية هى المرحلة التى يكون فيها الفرد

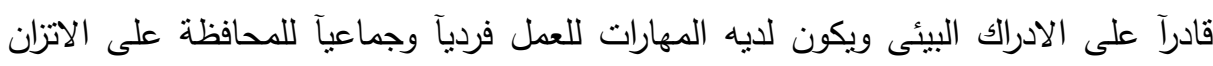

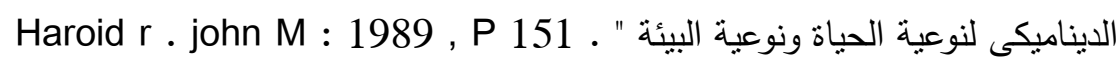
ويتضح من التعريفات السابقة لمفهوم الثقافة البيئية أنها تؤكد على أن الثقافة البيئية تتشمل المعرفة والمهارات والاتجاهات والقيم التى تمكن الفرد من حسن التصرف مع البيئة

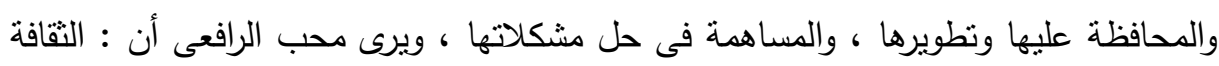

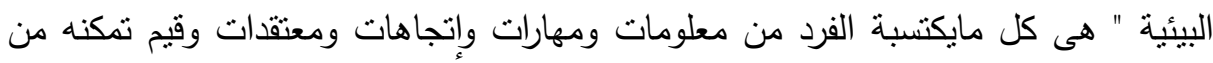
حسن التصرف مع البيئة والحفاظ عليها وتطويرها والمساهمة فى حل مشكلاتها ، ويكون قادرآ

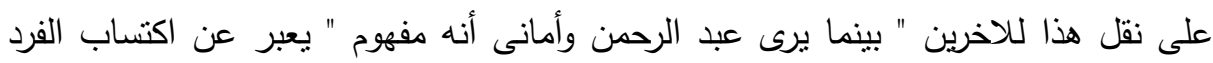

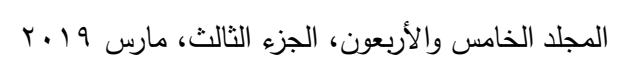


للمكونات المعرفية، والاففعالية والسلوكية من خلال تفاعله المستمر مع بيئته، والتي تسهم في

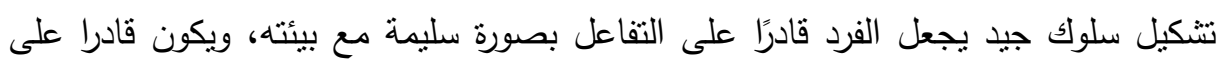

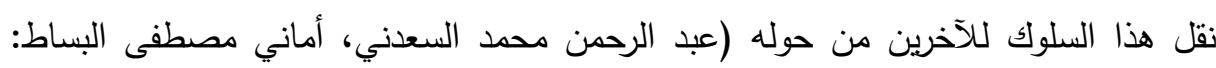

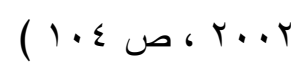
مصادر إكتساب الثقافة البيئية:ورلأسرة دورها في اكتساب الفرد التقافة التي تساعده على التأمل مع البيئة المحيطة سواء أكانت بيئة طبيعية أو مشيدة ، ومحتوى نلائك الثقافة بتضمن

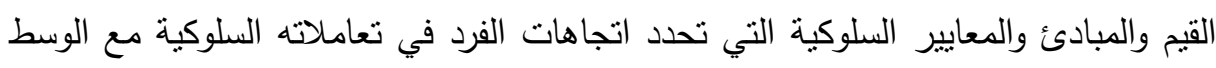

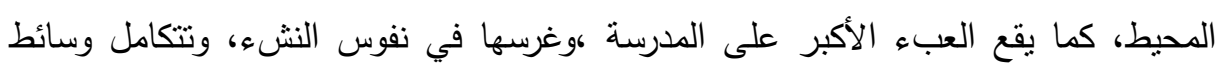
التنشئة في إثارتها فالثقافة البيئية تتضمن الإجراءات الوقائية التي تؤدي إلى الحماية والحفاظ

$$
\text { على البيئة . }
$$

إقتران مفهوم البيئة بالثقافة: وبذللك يتضح لنا أن اقتران مفهوم البيئة بالثقافة يعبر عن عدة

$$
\text { أمور منها: }
$$

• إن الوعي بمشكلات البيئة وعي مكتسب من المؤسسات المختلفة وأهمها الأسرة والمدرسة. • كما أن هذا الاقتران بين المفهومين يعبر عن جانب مهم يعد مدخلا أساسيا لتتمية النقافة

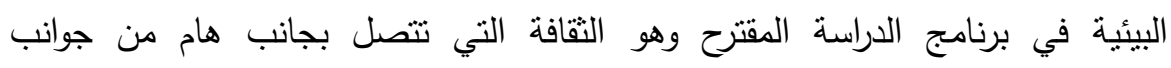

الثخصية ، وهو السلوك الذي يتوقف عليه نجاح برامج تتمبة التقافة البيئية.

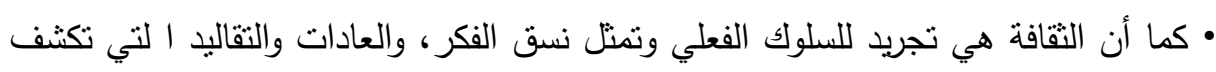

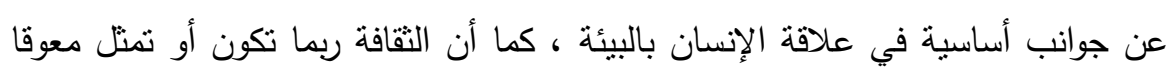

من معوقات تتمية النقافة البيئية.

• كما أن النقافة والبيئة يعبران عن فكرة الانتقال والاكتساب فالتقافة كما هو معروف تعبر عن جوانب مكتسبة تتنقل عبر الأجيال وهي أحد المداخل التتموية المهمة.

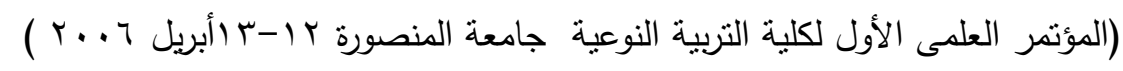

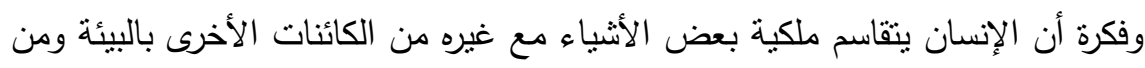
هنا لابد من الأسرة والمدرسة ومستوى الوعي الذي يرسخ في عقله ووجدانه تجاه هذه الملكية 
من مؤسسات عامة ووسائل مواصلات ، ومصادر طبيعية بأنواعها. (احمد يحيي عبد الحميد:

ومع ارتباط التربيه البيئيه بالتوجهات الحديثه في مجال التربيه العلميه ومع ظهور التقافة

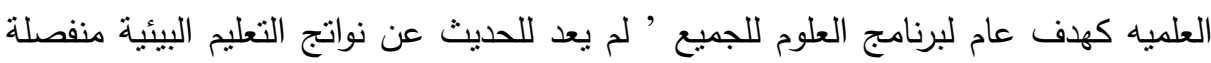

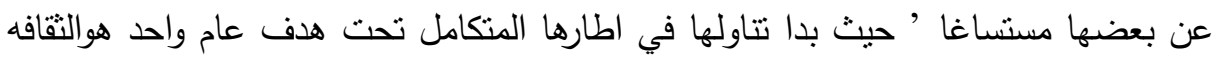

البيئية.

بامكان الثقافه البيئية، إلي جانب الثقافه الدينيه وتراث الانسانيه بمجمله، أن تؤدي دورا مساندا لحمايه عناصر البيئيه المتتوعه من الاشجار والحيوانات وغيرها، عبر نشر فضائل الدفاع عن العناصرالبيئية المنتوعة وحمايتها من عبث العابثين.

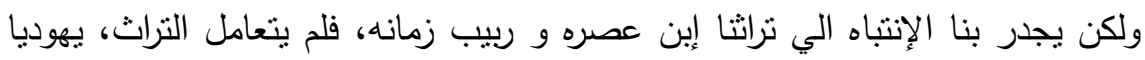

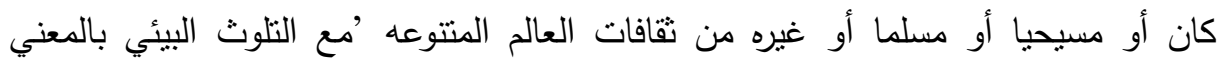

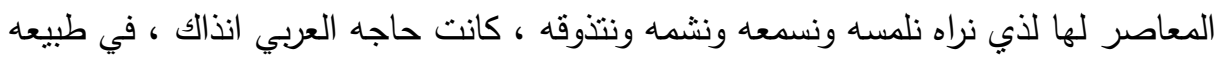

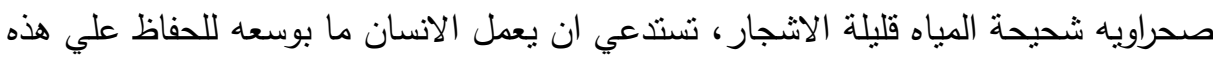

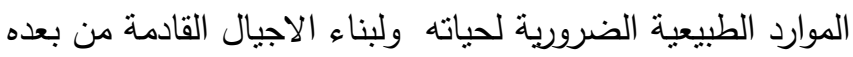

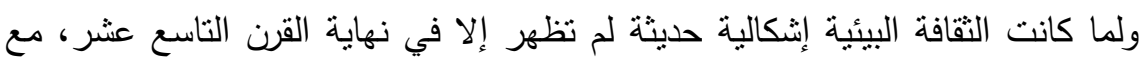
اشتداد الثورة الصناعيه و قدرتها التلويثية الهائلة للبيئية، بات من الضروري رفع مستوي الوعي الهي لهاتيه

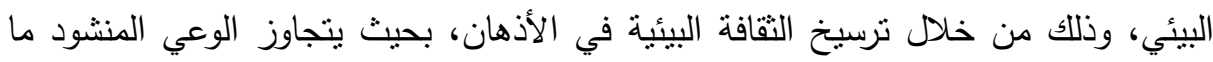

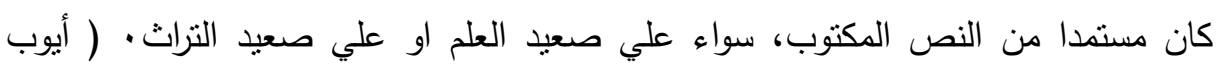

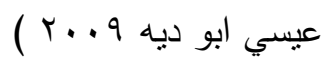
فالتقافه المعاصره ينبغي أن ترتقي كي تعالج هذا المد التدميري الهائل الذي يطال البيئيه علي نحو غير مسبوق في التاريخ، لذلك وفي مواجهة الضرر العظيم بالبيئة، نطمح ان نجعل نظافة البيئة وترشيد استهلاكنا لمواردها المحدودة ثقافة عامة ومتصلة بين الأجيال، بحيث نبدا من تقويم انفسنا من خلال الممارسات الصديقة للبيئة، كتوفير الطاقة في بيوتتا ومدارسنا وأماكن عملنا والامتتاع عن ايذاء الطبيعه وحماية الطبيعة بنظامها البيئي المتكامل

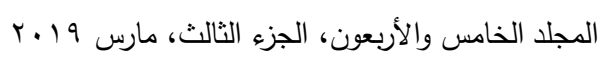


Ecosystem ومن ثم ننطلق نحو نشر الثقافة البيئية العامة بين الناس. ( أيوب عيسي أبو ديه مرجع سابق ) يري البعض ان الثقافة البيئية تمنل الحد الاعلي من الخبرات البيئية التي ينبغي للفرد ان

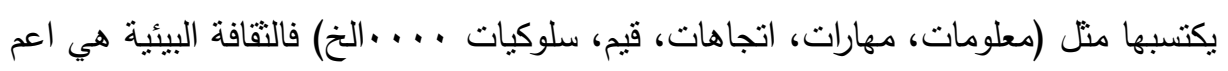
واشمل واعمق. إن الثقافه البيئية كمرادف غير مباشر للتعلم الايكولوجي والتربية البيئية هي عملية تطوير لوجهات النظر والمواقف القيمة وجملة المعارف والكفاءات والقدرات والتوجهات السلوكيه وجمله النتائج الصادرة عن عملية النطوير هذه، وذلك من اجل حماية البيئة والحفاظ عليها.

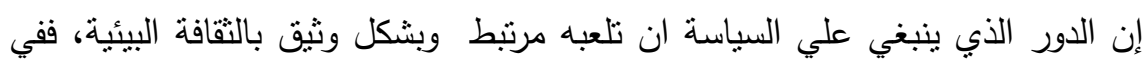

الوقت الذي تطمح فيه السياسة البيئية لحل المشاكل البيئية باستخدام إجراءات تقنيه وإداريه

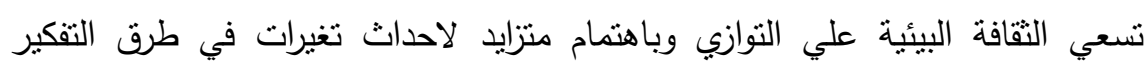
والسلوك البيئي عند الانسان، حيث ان جسر العبور الي مجتمع بملك صفات الاستمراريه يتم

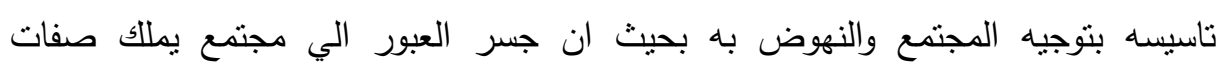

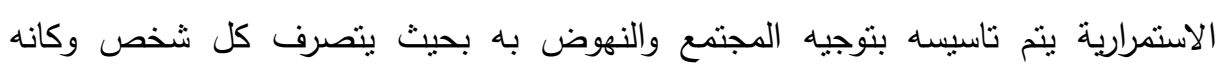

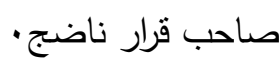

\section{إجباعايت الهمهث}

للاجابة عن أسئلة البحث والتأكد من صحة فروضه تم ما يلى: الهى أولا: إعداد قائمة القضايا البيئية: لإعداد هذه القائمة تم مراجعة العديد من الدارسات والبحوث المرتبطة بموضوع البحث ومنها دراسة:

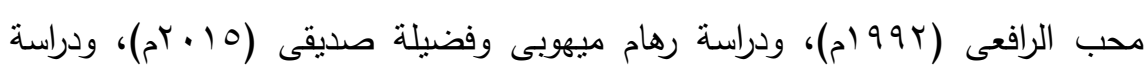

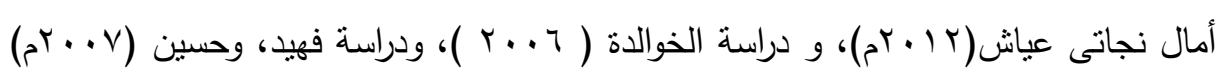

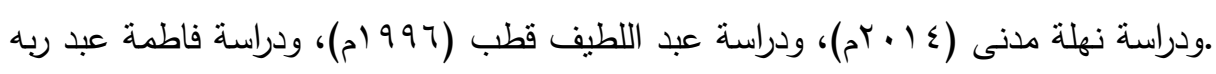
$\cdot(r+10)$ 
وتم إعداد القائمة فى صورتها الاولية وتم عرضها على مجموعة من المحكمين المتخصصين حيث أبدو مجموعة من الملاحظات النى نم تعديل القائمة فى ضوئهها. القائمة فى صورتها النهائية:

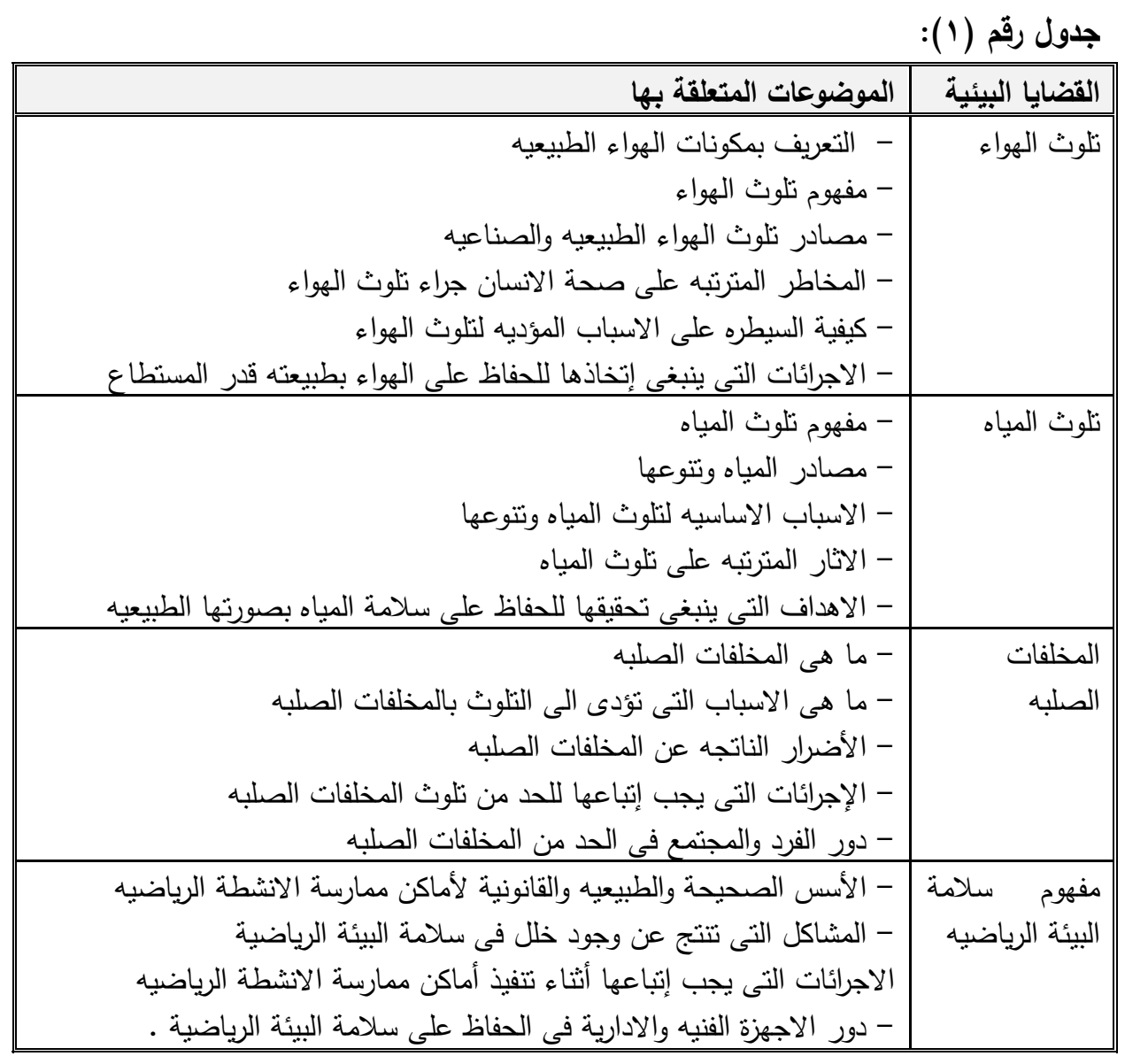


ثانياً: إعداد البرنامج:

جدول رقم(ץ): المحور الاول: محور تلوث الهواء

\begin{tabular}{|c|c|c|c|c|}
\hline الأنثطة & الوسائل التعليمية & طرق التدريب & المحتوى & الأهداف \\
\hline & 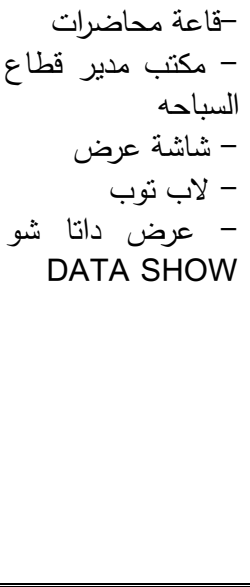 & ومناقتشاترات & 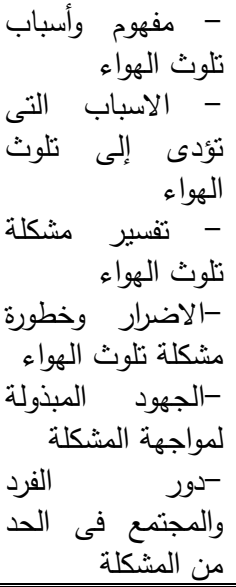 & 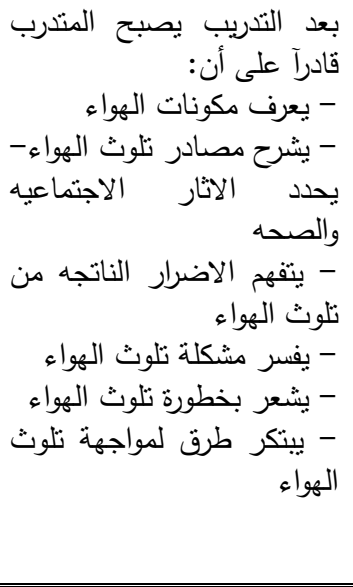 \\
\hline
\end{tabular}

جدول رقم(ץ): المحور الثانى: محورتلوث المياه

\begin{tabular}{|c|c|c|c|c|}
\hline الانثطة & الوسائل التعليمية & التدريب & المحتوى & الاهداف \\
\hline & 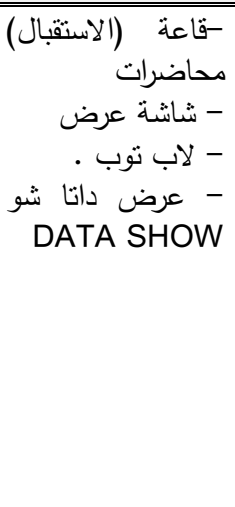 & - & 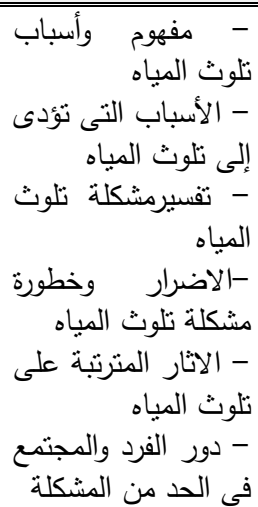 & 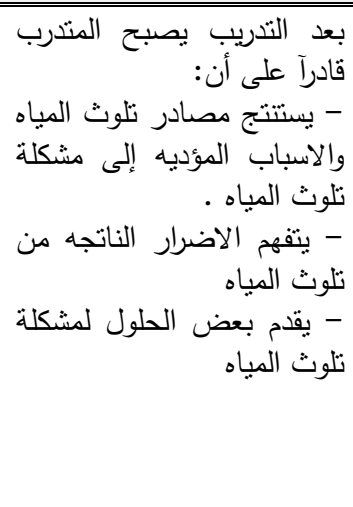 \\
\hline
\end{tabular}




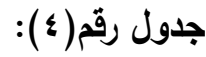

المحور الثالث: محور تلوثالمخلفات الصلبة

\begin{tabular}{|c|c|c|c|c|}
\hline الانشطة & الوبسائل التعليمية & طرقب & المحتوى & الاهداف \\
\hline 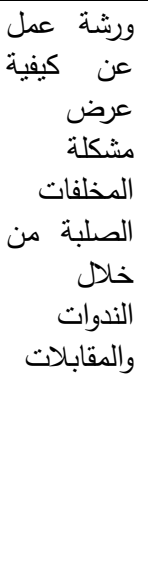 & 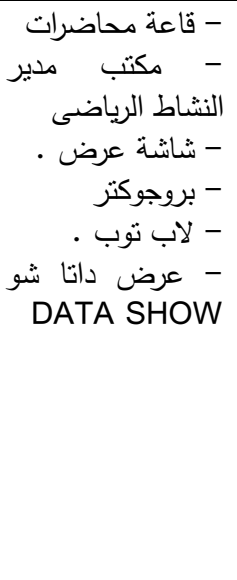 & ل & 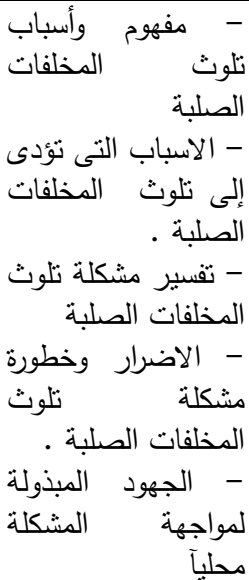 & 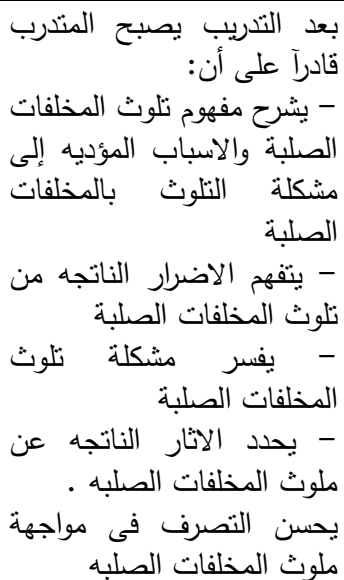 \\
\hline
\end{tabular}

جدول رقم (•)

المحور الرابع: محورثقافة سلامة البيئة الرياضية

\begin{tabular}{|c|c|c|c|c|}
\hline الانشطة & الوسائل التعليمية & طرق التدريب & المحتوى & الاهداف • \\
\hline 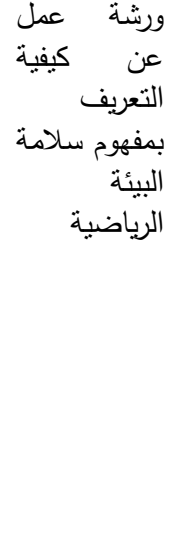 & 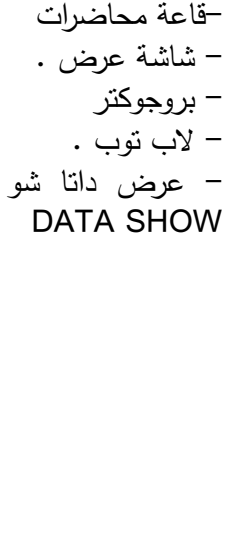 & 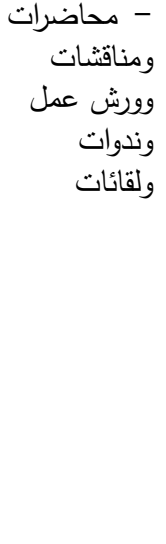 & 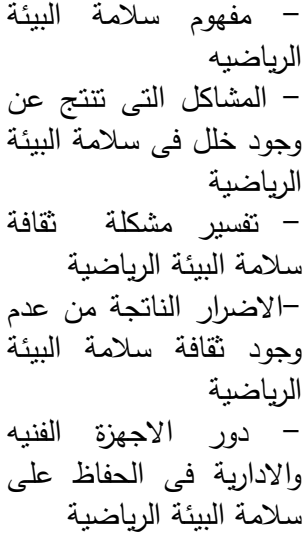 & 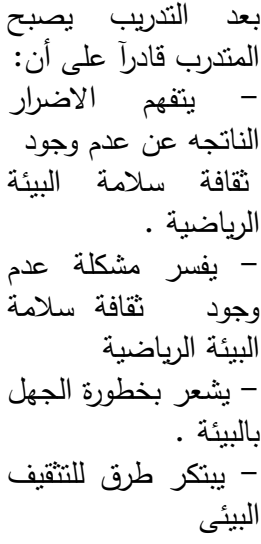 \\
\hline
\end{tabular}


ثالثآ: (1) إعداد إختبار المعارف البيئية: ا. تحديد الهدف من الاختبار: هدف الاختبار إلى: التعرف على مدى إكتساب الافراد للمعلومات البيئية التى جاءت بالبرنامج r. المحاور التي يتضمنها الاختبار : القضايا البيئيه فى ضئهواءئه ما انتهت إليه قائمة قضايا البيئة ومشكلاتها فى صورتها النهائية r. صياغة مفردات الاختبار • تم صياغة مفردات الاختبار بطريقة الاختبار من متعدد، تضمن ونه

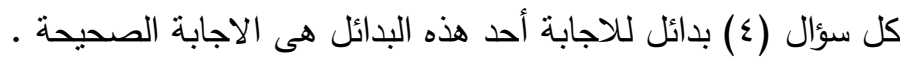

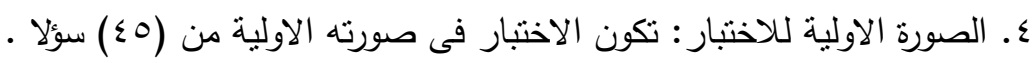

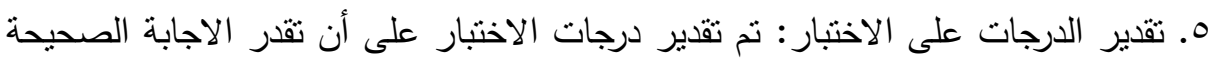

$$
\text { (بدرجة واحده) والاجابه غير الصحيحه (صفر) ) }
$$

T. ضبط الاختبار : نم ضبط إختبار المعارف البيئية من خلال حساب صدقه الهابه بعرضه على مجموعة من المحكمين للتأكد من:

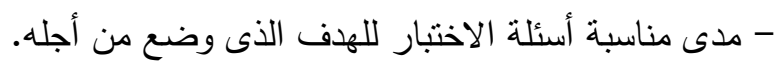
- مدى ملاء مة العبارات التي وردت في الاختبار لمستوى المدربين عينة الدراسة. - مدى ملاء ئمة البدائل لكل عبارات الاختبار .

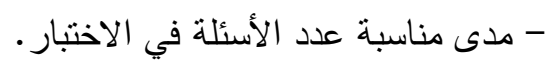
- مدى ملائمة التعليمات الخاصة الاختبار . وبعد إستعراض أراء المحكمين وجد إتفاق كبير بينهم مما يدل على صدق الاحبن الاختبار . ** صدق الإتساق الداخلي إختبار المعارف البيئة: قام الباحثون بحساب صدق الإتساق الداخلي ومعامل الارتباط الدصحح لكل محور بإجمالي الاختبار لحساب الصدق كالآتي: 
جدول رقم (؟): ثبات العبارات لأبعاد أختبار المعارف البيئية

\begin{tabular}{|c|c|c|c|}
\hline معامل التصحيح & معامل الصدق & \multicolumn{2}{|c|}{ أبعاد الاختبار } \\
\hline \multirow{2}{*}{$\cdot, \wedge 4$} & $\left({ }^{(* ")}\right),, V \leqslant V$ & معامل ارتباط بيرسون & \multirow{2}{*}{ تلوث الهواء } \\
\hline & $\cdot, \cdots 1$ & الدلالة المعنوية & \\
\hline \multirow{2}{*}{$\cdot, \wedge \varepsilon$} & $\left({ }^{* *}\right),, V \pi 1$ & معامل ارتباط بيرسون & \multirow{2}{*}{ تل تلوث الماء } \\
\hline & $\cdot, \ldots 1$ & الدلالة المعنوية & \\
\hline \multirow{2}{*}{$\cdot, \wedge \vee$} & $(* *), \vee \vee \vee \cdot$ & معامل ارتباط بيرسون & \multirow{2}{*}{ المخلفات الصلبة } \\
\hline & $\cdot,, \cdot 1$ & الدلالة المعنوية & \\
\hline \multirow{2}{*}{$\cdot, 9$. } & $(" 1) \cdot, \lambda 17$ & معامل ارتباط بيرسون & \multirow{2}{*}{ ثقافة سلامة البيئة الرياضية } \\
\hline & $\cdot, \cdot, 1$ & الدلالة المعنوية & \\
\hline
\end{tabular}

من الجدول السابق لصدق الاتساق الداخلي للاختبار نجد أن قيم معامل الارتباط دالة

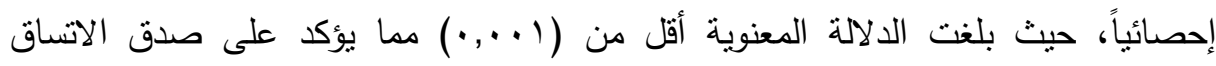

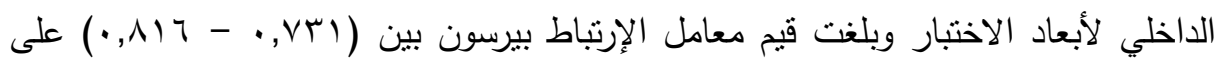

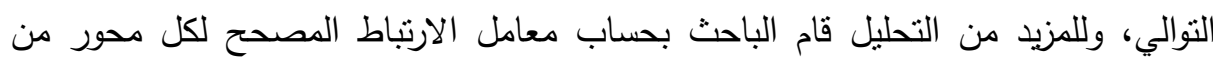
محاور الاختبار بجانب حساب معامل الارتباط كما هو مبين بالجدول أعلاه، ووجد أن معامل

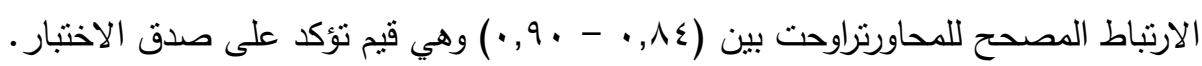

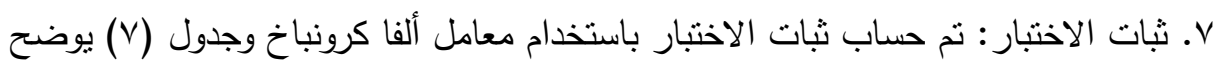
معامل الثبات لكل محور من محاور الاختبار وللاختبار ككل. جدول رقم (V): ثبات العبارات لأبعاد إختبار المعارف البيائية

\begin{tabular}{|c|c|c|}
\hline معامل ثبات ألفا & عدد العبارات & أبعاد الإختبار \\
\hline$\cdot, 79$ & 11 & تلوث الهواء \\
\hline$\cdot, V \leqslant \Gamma$ & 1. & تلوث الماء \\
\hline$\cdot, 709$ & V & المخلفات الصلبة \\
\hline$\cdot, V Y$. & $\Lambda$ & ثقافة سلامة البيئة الرياضية \\
\hline$\cdot, \wedge \cdot 0$ & ry & إجمالي الاختبار \\
\hline
\end{tabular}

A. الصوره النهائية لاختبار المعارف البيئية:

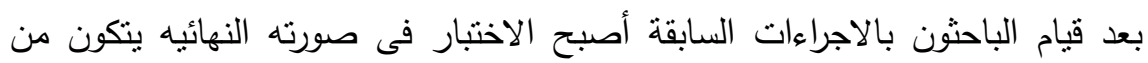

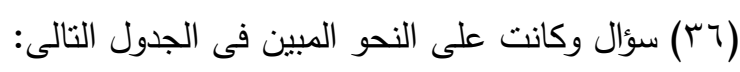


جدول رقم (^): القضايا البيئية المختلفة وعدد الاسئلة لكل موضوع وأرقامه الاما

\begin{tabular}{|c|c|c|}
\hline آرقام أسئلة كل موضوع & عدد الاسئلة & الموضوعات \\
\hline $11: 1$ & 11 & محور تلوث الهواء \\
\hline $19: 15$ & $\Lambda$ & محور تلوث المياه \\
\hline YA:Y. & 9 & المخلفات الصلبة \\
\hline rq: & $\Lambda$ & محور ثقافة سلامة البيئة الرياضية \\
\hline r : 1 & ד & المجمــــوع \\
\hline
\end{tabular}

(Y) (إعداد مقياس الاتجاهات البيئية:

** الهيف من المقياس:هدف المقياس إلى التعرف على الاتجاهات البيئية لدى المدربين الرياضين مجموعة البحث.

*** عبارات المقياس:تم صياغة مفردات المقياس فى صورة مواقف يلى كل موقف ثلاثة استجابات وذللك للقضايا البيئية التى جاءت باعه بالقائمة.

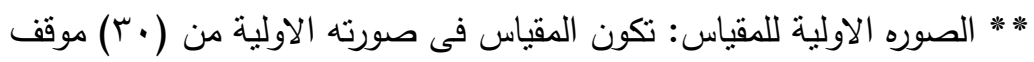
صدق المقياس: تم عرض المقياس على مجموعة من الساده المحكمين، وقد وجد إتفاق كبير فى أراء الساده المحكمين حول سلامة وضع وصياغة العبارات ومناسبتها لمقياس الاتجاهات

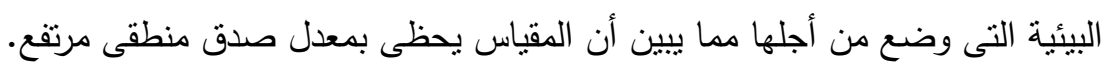

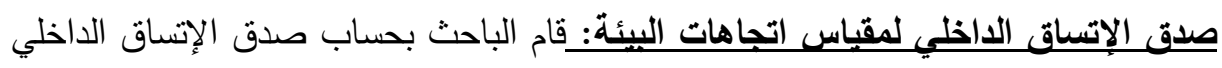
ومعامل الارتباط المصحح لكل محور بإجمالي المقياس لحساب الصدق كالآتي: جدول رقم (9): ثبات العبارات لأبعاد مقياس اتجاهات البيئة

\begin{tabular}{|c|c|c|c|}
\hline التصحيح & الصدق & \multicolumn{2}{|c|}{ أبعاد الاختبار } \\
\hline \multirow{2}{*}{$\cdot, \wedge \mathrm{V}$} & ("I").,VVV & معامل ارتباط بيرسون & \multirow{2}{*}{ تلوث الهواء } \\
\hline & $\cdot, \cdots 1$ & الدلالة المعنوية & \\
\hline \multirow{2}{*}{$\cdot$, גד } & $(" \nabla) \cdot, V \leq V$ & معامل ارتباط بيرسون & \multirow{2}{*}{ تلوث الماء } \\
\hline & $\cdot, \cdots 1$ & الدلالة المعنوبة & \\
\hline \multirow{2}{*}{$\cdot, 9$. } & $(")^{*} \cdot, A Y Y$ & معامل ارتباط بيرسون & \multirow{2}{*}{ ل لمخلفات الصلبة } \\
\hline & $\cdot, \cdots 1$ & الدلالة المعنوية & \\
\hline \multirow{2}{*}{$\cdot, 91$} & $\left({ }^{\circ \circ} \cdot, \wedge Y \wedge\right.$ & معامل ارتباط بيرسون & \multirow{2}{*}{ ققافة سلامة البيئة الرياضية } \\
\hline & $\cdot, \cdots 1$ & الدلالة المعنوية & \\
\hline
\end{tabular}


من الجدول السابق لصدق الاتساق الداخلي للاختبار نجد أن قيم معامل الارتباط دالة

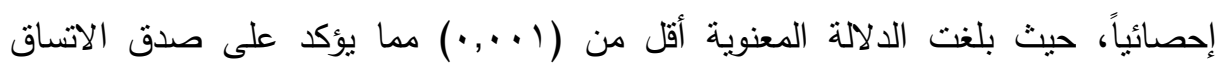

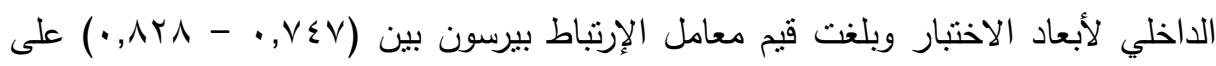

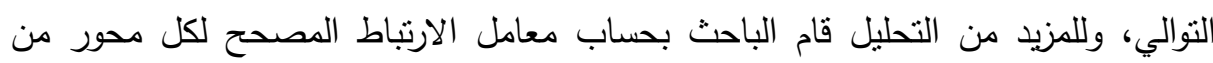
محاور الاختباربجانب حساب معامل الارتباط كما هو مبين بالجدول أعلاه، ووجد أن معامل

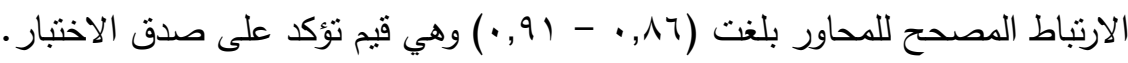
ثبات المقياس: الصورة النهائية لمقياس الإتجاهات البيئية:

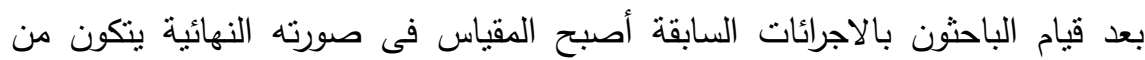

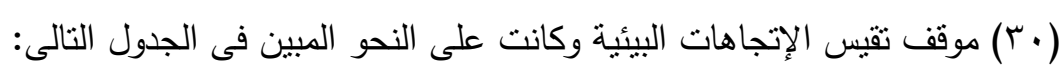

\begin{tabular}{|c|c|}
\hline عدد المواقف & الموضوعات \\
\hline 1 & محور تلوث الهواء \\
\hline 7 & محور تلوث المياه \\
\hline$\Lambda$ & محور المخلفات الصلبة \\
\hline$\Lambda$ & محور ثقافة سلامة البيئة الرياضية \\
\hline$r$ & 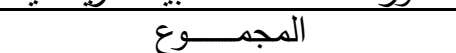 \\
\hline
\end{tabular}

** ثبات مقياس اتجاهات البيئة: للتحقق من ثبات مقياس اتجاهات البيئة استخدم الباحث معادلة ألفا كرونباخ، ويوضح الجدول التالي معاملات الثبات الناتجة باستخدام هذه المعادلة. جدول رقم (11 (1): ثبات العبارات لأبعاد مقياس اتجاهات البيئة

\begin{tabular}{|c|c|c|}
\hline معامل ثبات ألفا & عدد العبارات & أبعاد المقياس \\
\hline$\cdot, V \backslash Y$ & $\Lambda$ & تلوث الهواء \\
\hline$\cdot, \wedge \wedge 0$ & 7 & تلوث الماء \\
\hline$\cdot, V 7 T$ & $\Lambda$ & المخلفات الصلبة \\
\hline$\cdot, \mathrm{V} \leqslant 1$ & $\Lambda$ & ثقافة سلامة البيئة الرياضية \\
\hline$\cdot, \wedge \wedge \mathrm{r}$ & $r$. & إجمالي الاختبار \\
\hline
\end{tabular}

يتضح من الجدول السابق أن قيم معاملات الثبات لأبعاد مقياس اتجاهات البيئة جميعها ، البار

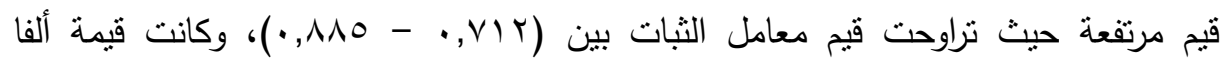

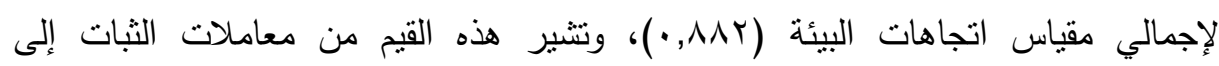


صلاحية المقياس للنطبيق وإمكانية الاعتماد على نتائجه والوثوق به.

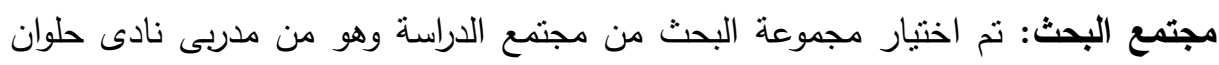
العام والبالغ عددهم ( • ب ) مدرب ومدربه موزعين على النالعاب المختلفة وتتراوح أعمارهم

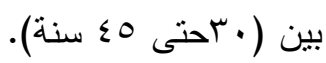

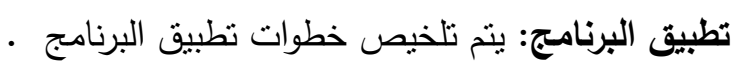
التطبيق القبلى للاختبار والمقياس: نم التطبيق القبلى لإختبار المعارف البيئية ومقياس

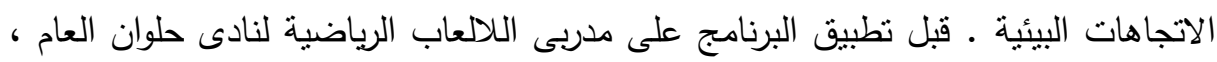

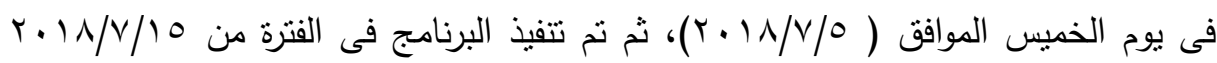

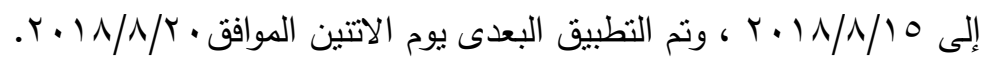

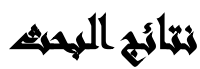

التحقق من صحة فروض البحث: الفرض الأول: توجد فروق ذات دلالة إحصائية بين متوسط درجات أفراد المجموعة

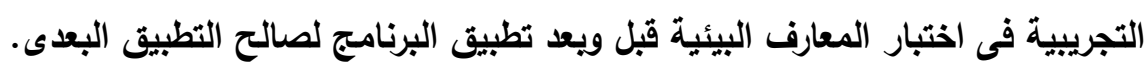
جدول (r I): اختبار (ت) (t-test) لحساب الفروف بين متوسط درجات التطبيق القبلي ومتوسط درجات التطبيق البعدي على اختبار المعارف البيئية

\begin{tabular}{|c|c|c|c|c|c|c|c|c|}
\hline \multirow{2}{*}{ التأثير } & \multirow{2}{*}{ عندالة } & \multirow{2}{*}{ "تيمة } & \multicolumn{2}{|c|}{ 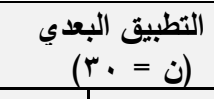 } & \multicolumn{2}{|c|}{ 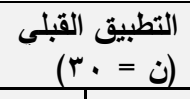 } & \multirow{2}{*}{$\begin{array}{r}\text { الارج } \\
\text { الكلية } \\
\end{array}$} & \multirow[t]{2}{*}{ أبعاد المقياس } \\
\hline & & & $\varepsilon$ & p & $\varepsilon$ & p & & \\
\hline$\cdot, 71$ & 1..., ••دال & $\varepsilon, \wedge 9$ & $1,9$. & $\mathrm{V}, \mathrm{VT}$ & $1, \vee 9$ & $\varepsilon, q \pi$ & 11 & تلوث الهواء \\
\hline 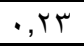 & 1.., , . دال & 1,04 & $r, 71$ & 7,7 & $r, T \varepsilon$ & $0, \varepsilon r$ & 1. & تلوث الماء \\
\hline., 09 & (..., ..دال & 0,17 & $1, \mathrm{r \Lambda}$ & $0, r V$ & 1,10 & $r, 1$ & $\mathrm{~V}$ & المخلفات الصلبة \\
\hline$\cdot, 0 \leqslant$ & 1 ..,.,دال & $\varepsilon, V)$ & $1, \leqslant r$ & $0, \varepsilon$ & $r, \cdot r$ & $r, i r$ & $\wedge$ & الرياضة سلاضية $\quad$ البيئة \\
\hline$\cdot, 7 \leqslant$ & 1 ..,.,دال & $0, r q$ & $\{, 71$ & ro, Ir & $0, \wedge 7$ & 17,7 & ד ד & المعلومات البيئية لاختبار \\
\hline
\end{tabular}


يتضح من الجدول السابق لحساب الفروق بين منوسط درجات النطبيق القبلي ومنوسط درجات النطبيق البعدي على اختبار المعارف البيئية ما يلي:

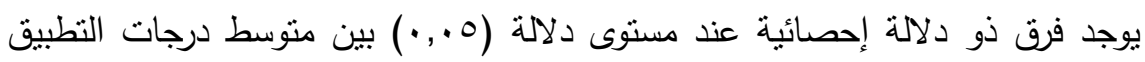

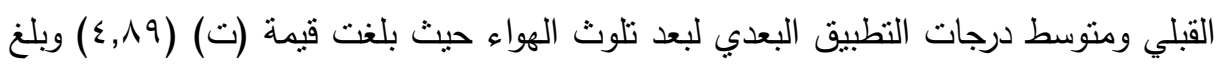

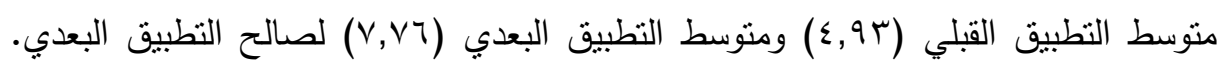
يوجد فرق ذو دلالة إحصائية عند مستوى دلالة (0., •) بين متوسط درجات التطبيق القبلي

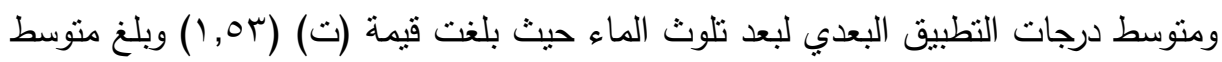

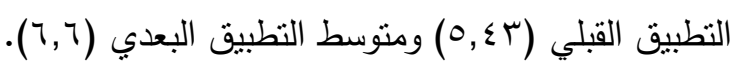
يوجد فرق ذو دلالة إحصائية عند مستوى دلالة (0., •) بين منوسط درجات النيطئ النطبيق

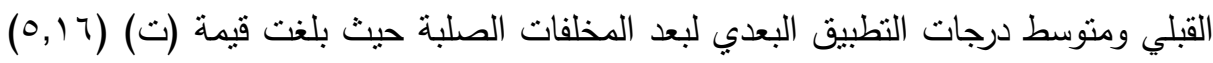

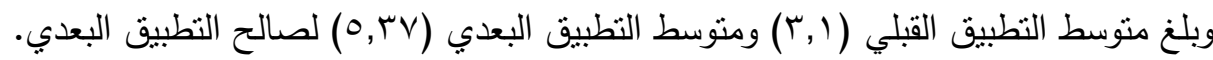
يوجد فرق ذو دلالة إحصائية عند مستوى دلالة (0., •) بين متوسط درجات النطبيق

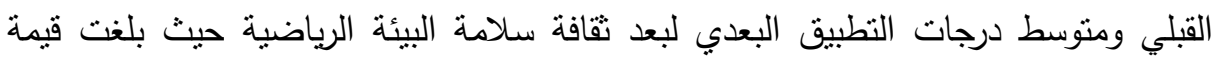

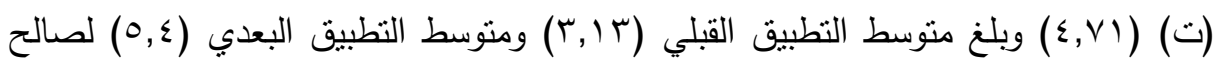
التطبيق البعدي. يوجد فرق ذو دلالة إحصائية عند مستوى دلالة (0., •) بين متوسط درجات النطبيق

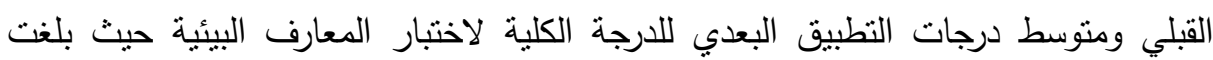

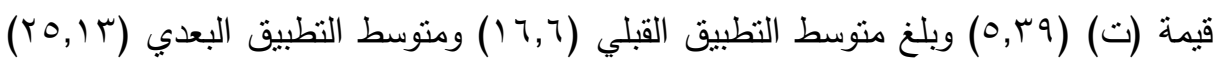
لصالح التطبيق البعدي. 


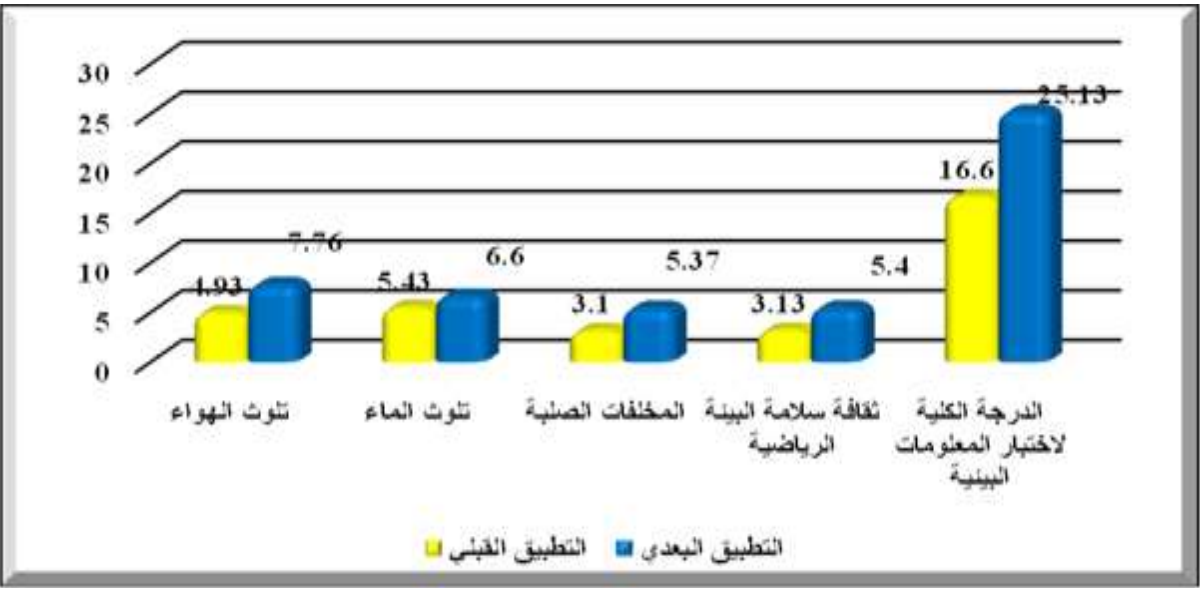

شكل (1)

الفروف بين منوسط درجات التطبيق القبلي ومتوسط درجات التطبيق البعدي على اختبار المعارف البيئية

الفرض الأول: توجد فروق ذات دلالة إحصائية بين متوسط درجات أفراد المجموعة التجريبية فى مقياس المعارف البيئية قبل ويعد تطبيق البرنامج لصالح التطبيق البعدى. جدول (ع ا) اختبار (ت) (t-test) لحساب الفروق بين متوسط درجات التطبيق القبلي ومتوسط درجات النطبيق البعدي على مقياس الدعارف البيئية جدول (r آ): اختبار (ت) (t-test) لحساب الفروق بين متوسط درجات التطبيق القبلي ومتوسط درجات التطبيق البعدي على مقياس الاتجاهات البيئية

\begin{tabular}{|c|c|c|c|c|c|c|c|c|}
\hline \multirow{2}{*}{ التأثبْ } & \multirow{2}{*}{ 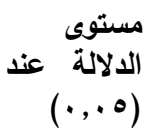 } & \multirow{2}{*}{ قتيمة } & \multicolumn{2}{|c|}{ 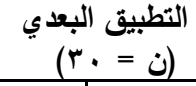 } & \multicolumn{2}{|c|}{ 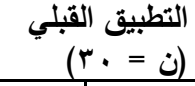 } & \multirow{2}{*}{ الكلية } & \multirow{2}{*}{ أبعاد المقياس } \\
\hline & & & $\varepsilon$ & م & $\varepsilon$ & r & & \\
\hline 07, & ".,., , •دال & $\varepsilon, 9 \leqslant$ & $r, Y Y$ & $1 Y, q$ & $r, \leqslant r$ & $9, \wedge$ & 17 & تلوث الهواء \\
\hline$\cdot, \leqslant V$ & , .., •.دال & $\varepsilon, \ldots$ & 1,79 & 11,1 & $r, 01$ & $\Lambda, 17 V$ & ir & تلوث الماء \\
\hline$\cdot, \varepsilon V$ & , .,.,.יدال & r, vo & $r, .0$ & $I T, Y V$ & $r, Y \wedge$ & $9, \varepsilon r$ & 17 & المخلفات الصلبة \\
\hline$\cdot, 0 \mathrm{~V}$ & •., , •دال & $0, \ldots$ & r,vo & $1 T, V T$ & $1, \wedge 1$ & $1 \cdot, 0 \mathrm{~V}$ & 17 & الرياضية سلامة البيئة \\
\hline$\cdot, 07$ & • .., •دال & 7,11 & 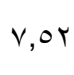 & 0 . & $7, \vee 0$ & $r v, q 7$ & 7. & الاتجاهات الكليية لمقياس \\
\hline
\end{tabular}


يتضح من الجدول السابق لحساب الفروق بين منوسط درجات التطبيق القبلي ومنوسط

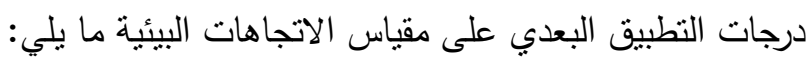
يوجد فرق ذو دلالة إحصائية عند مستوى دلالة (0., •) بين منوسط درجات لاتهات النطبيق

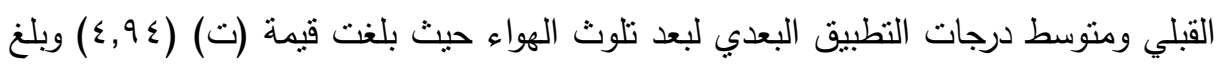

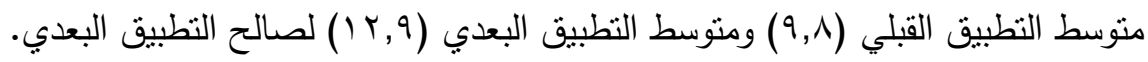
يوجد فرق ذو دلالة إحصائية عند مستوى دلالة (0., •) بين متوسط درجات النطبط النطبيق

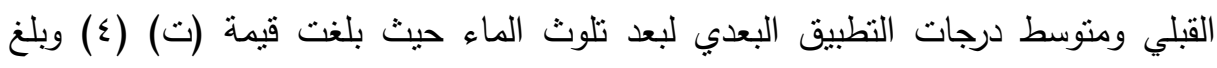

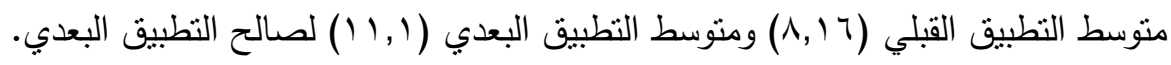
يوجد فرق ذو دلالة إحصائية عند مستوى دلالة (0., •) بين متوسط درجات النطبيق

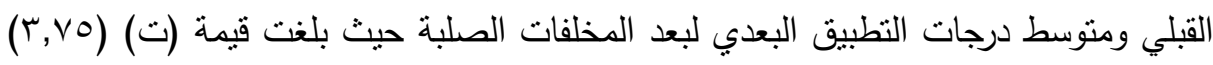

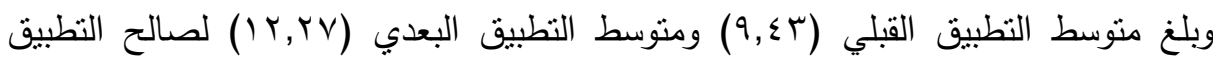
البعدي. يوجد فرق ذو دلالة إحصائية عند مستوى دلالة (0., •) بين منوسط درجات النطبيق

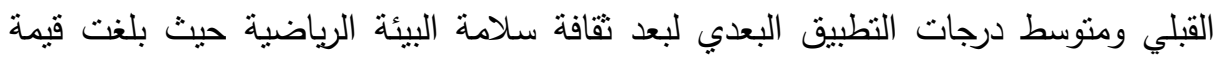

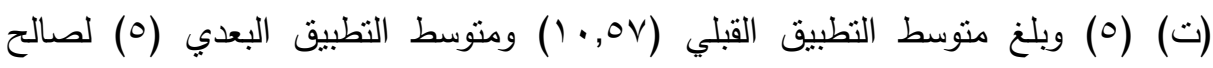
التطبيق البعدي. يوجد فرق ذو دلالة إحصائية عند مستوى دلالة (0., •) بين منوسط درجات النطبيق

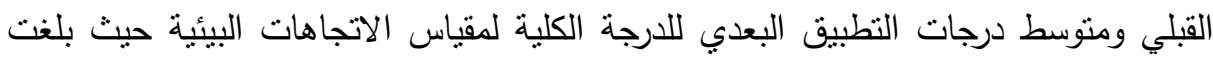
قيمة (ت) (T,11) وبلغ منوسط النطبيق القبلي (TV,9T) ومنوسط النطبيق البعدي(.0) 


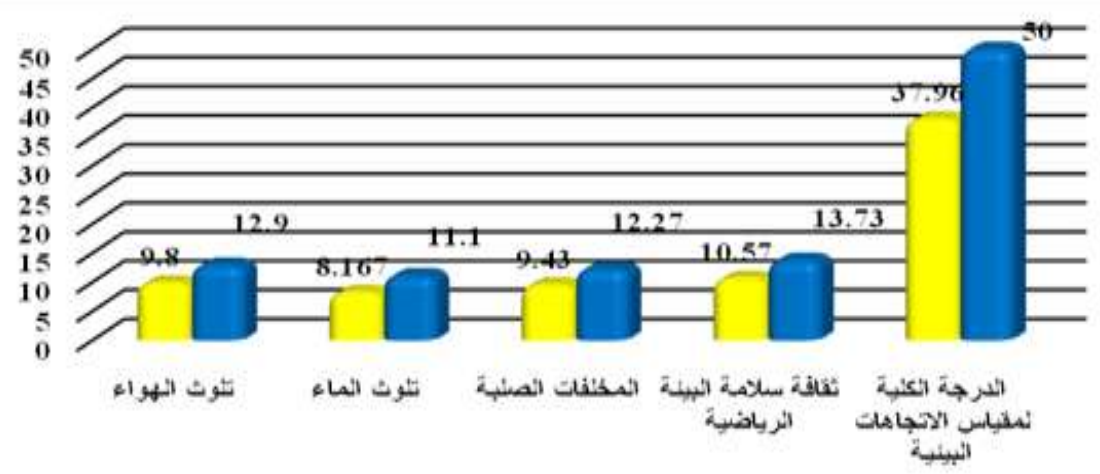

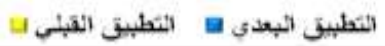

شكل (r)

الفروق بين منوسط درجات التطبيق القبلي ومتوسط درجات التطبيق البعدي على مقياس الاتجاهات البيئية

الفرض الثانى: توجد فروق ذات دلالة إحصائية بين متوسط درجات أفراد المجموعة

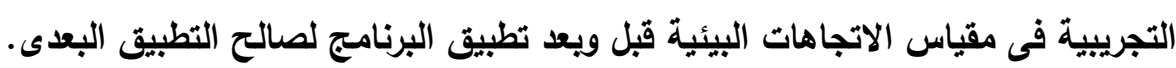
جدول (10) اختبار (ت) (t-test) لحساب الفروق بين منوسط درجات التطبيق القبلي ومتوسط درجات التطبيق البعدي على مقياس الاتجاهات البيئية تعقيب عام على النتائج: يتضح من نتائج الدراسة أن برنامج التقافة البيئية المعد من قبل الباحثونكان له فاعلية

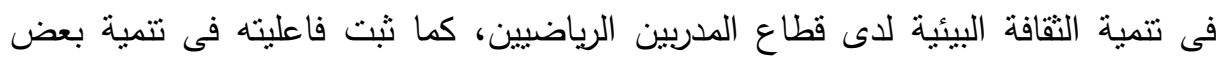

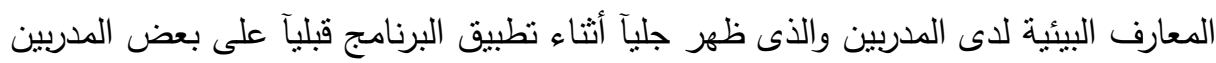

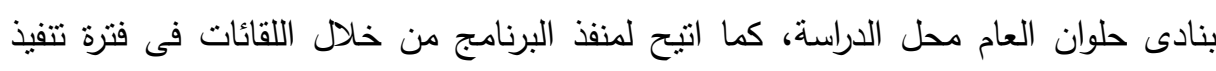

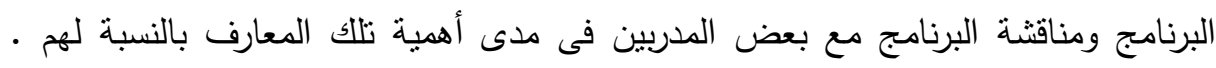

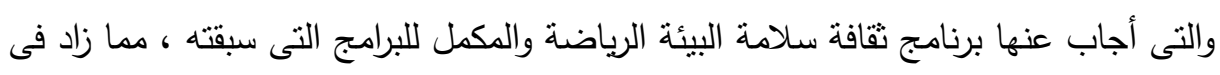

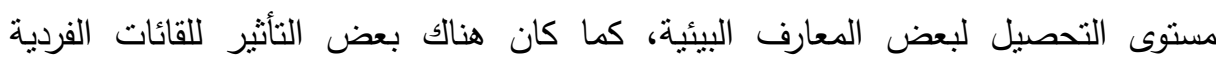

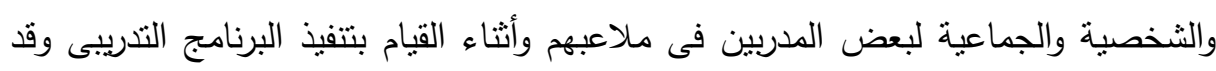

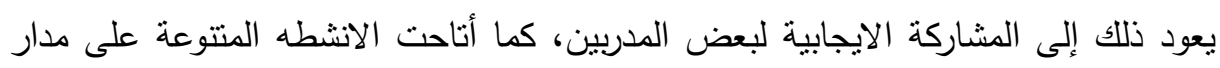
254

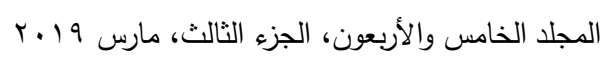


فترة تتفيذ البرنامج إلى زيادة التحصيل المعرفى والتىى أثزت فى تحسين مستوى التقافة البيئية لديهم. كما تم توزيع فيما يزيد عن خمسون نموذج اختبار المعارف البيئية ومقياس الإتجاهات البيئية على المدربين ولم يتم تحصيل إلا ثلاثتن بصعوبة بالغة وهم مانم إقناعهم بصعوبة.

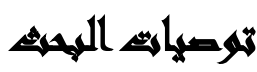

1- تطبيق البرنامجالمقترح على المدربيين الرياضبين لتنمية الثقافة البيئية لديهم. r- العمل على إرسال برنامج التقافة البيئية مطور فى شكل كتيب يتم توزيعه على القائمين على إدارات الهيئات الرياضية عن طريق وزارة الثباب والرياضه. ب-محاولة تطبيق البرنامج التدريبى المقترح على القائمين على إدارات الانشطة الرياضيه بالانديه .

ع - الاهتمام بالمدربيين الرياضيين ووضع برامج بيئية للتعليم المستمر .

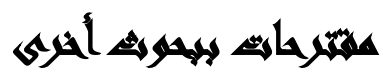

1- تصميم برامج لتتمية الثقافة البيئية خاص لطلبة كليات التربية الرياضية بنين وبنات. r- تقييم البرامج الحاليه للرياضيين.

\section{المراني}

أحمد يحيي عبد الحميد (997 ()): الاسرة والبيئة ، المكتب الجامعى الحديث، الاسكندرية

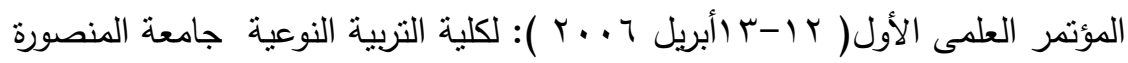

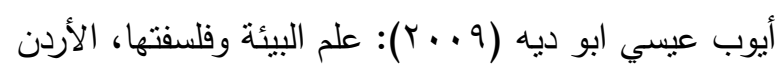

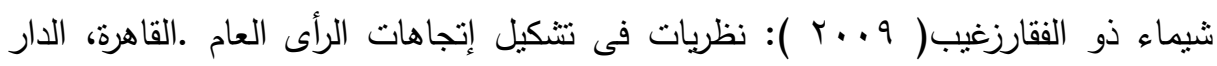
المصرية اللبنانية

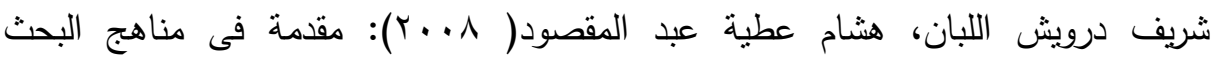
الاعلامى،القاهرة الدار العربية للنشر والتوزيع 


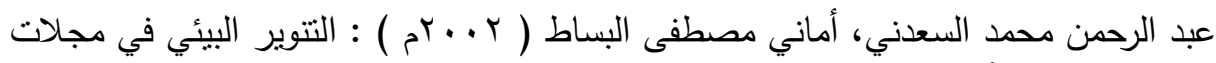

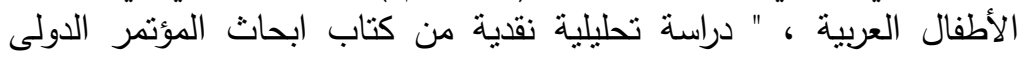

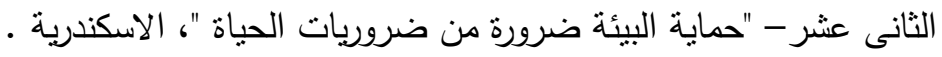

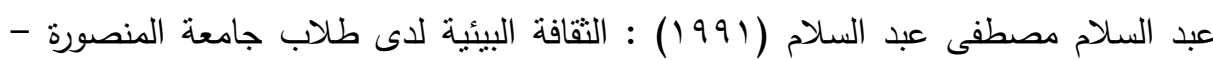

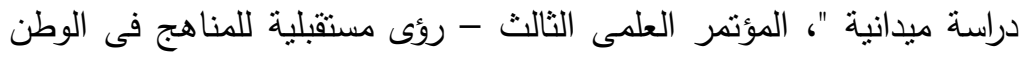

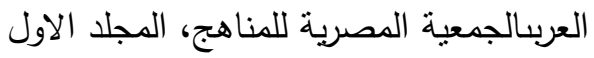

عبد اللطيف سيد عبد اللطيف قطب(997 ام): الثقافة البدنية والترويحية فى مضمون المقررات الدراسية للمرحلة الإعدادية - رسالة ماجستير - نربية رياضية بنية البنين

فاطمة محمد حامد عبد ربه (10 • rم): فاعلية برنامج تربية حركية مقترح لتتمية القيم البيئية

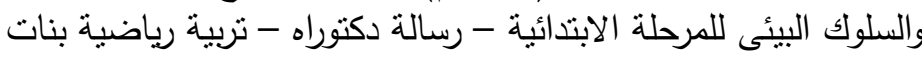

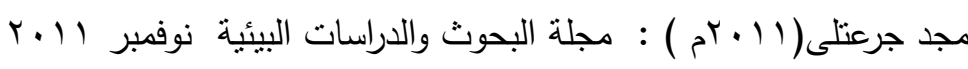

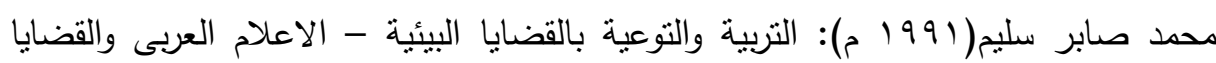
البيئية، معهد الدراسات والبحوث العربية

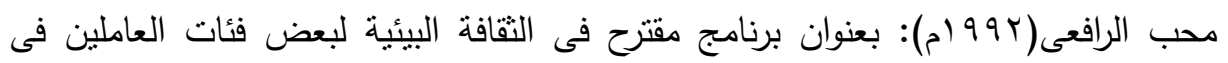

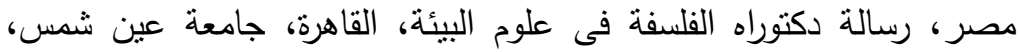

معهد الدراسات والبحوث البيئية ـ قسم التربية والنقافة البيئية

Harold r., john M . : AprotoypeEnv .Ed .Curricuium For The midie

School, U. S.A. , 1989 , 
مجلة العلوم البيئية

معهد الدراسات والبحوث البيئة - جامعة عين شمس

\title{
DEVELOPING SOME ELEMENTS OF ENVIRONMENTAL CULTURE AMONG SOME PHYSICAL EDUCATION (PE)TRAINERS
}

Mohamed E. M. Deeb ${ }^{(1)}$ Abdel Messeh S. Abdel Messeh ${ }^{(1)}$; and Farouk E. Abdel Wahhab ${ }^{(2)}$

1) Institute of Environmental Studies and Research, Ain Shams University 2) Faculty of Arts, University of Minya

\begin{abstract}
This study's purpose is to develop some environmental culture elements as well as (environmental knowledge and attitudes) through a program designed specifically for that purpose.

A checklist of the most important environmental issues is designed including what the one in charge of the educational instructor of physical sports should be aware of (sports couch) in Helwan General Club in addition to preparing a program for environmental culture.

A Scale of Measuring Environmental Culture is designed and presented to those couches. The researchers have used the experimental method, being applied on a group of those in charge of training $(n=40)$ couches. The program is applied in the time duration from (15/7/2018 to 10/8/2018). Moreover, a program knowledge and scale of environmental attitudes are administered on the study sample. The results indicate statistically significant differences exist between average scores of the study sample pre/post application of the cognitions test, pre/post application of the program, in favor of the post-application. Also, there are statistically significant differences exist between average scores of the study sample pre/post application of the scale of environmental attitudes of the study group, in favor of the post-application, indicating the effectiveness of the proposed program in developing environmental culture among physical education trainers.

The researchers have recommended the necessity of benefitting from the proposed program.
\end{abstract}

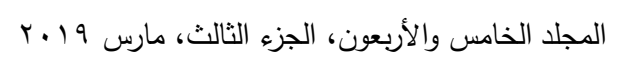

